Article

\title{
The Evaluation of Exogenous Application of Salicylic Acid on Physiological Characteristics, Proline and Essential Oil Content of Chamomile (Matricaria chamomilla L.) under Normal and Heat Stress Conditions
}

\author{
Mojtaba Ghasemi ${ }^{1,2}$, Mohammad Modarresi ${ }^{2, *}$, Nadali Babaeian Jelodar ${ }^{3}$, Nadali Bagheri ${ }^{3}$ and \\ Abbas Jamali ${ }^{4}$ \\ 1 Department of Research and Development, Sea Bioprospecting Co., Ltd., \\ Tangestan Science and Technology Incubator, Persian Gulf Science and Technology Park, \\ Bushehr 7515797414, Bushehr, Iran; m.ghasemi22@gmail.com \\ 2 Department of Plant Breeding, Faculty of Agriculture and Natural Resources, Persian Gulf University, \\ Bushehr 7561158818, Bushehr, Iran \\ 3 Department of Plant Breeding and Biotechnology, Faculty of Crop Science, Sari Agricultural Sciences and \\ Natural Resources University, Sari 578, Mazandaran, Iran; n.babaeian@sanru.ac.ir (N.B.J.); \\ n.bagheri@sanru.ac.ir (N.B.) \\ 4 The Persian Gulf Research and Study Institute, Persian Gulf University, Bushehr 7561158818, Bushehr, Iran; \\ jamalia111@yahoo.com \\ * Correspondence: modarresi@pgu.ac.ir; Tel.: +98-7734221461
}

Academic Editor: Nieves Goicoechea

Received: 15 May 2016; Accepted: 19 July 2016; Published: 25 July 2016

\begin{abstract}
The objective of this study was to investigate the effect of exogenous application of salicylic acid concentrations on the physiological and biochemical traits and essential oil content of chamomile under normal and heat stress conditions as induced by delayed sowing. The experiments were conducted during 2011-2012 as a factorial using a randomized complete block design with three replications, in a very hot region. The factors included five salicylic acid concentrations ( 0 (control), 1, 10, 25 and $100 \mathrm{mg} \cdot \mathrm{L}^{-1}$ ) and three chamomile cultivars (Bushehr, Bona, Bodegold). The seeds of chamomile were sown on two different sowing dates including an optimum planting date and a late planting date. The physiological traits (plant height, capitol diameter, 1000 grain weight, fresh and dried flower weight), total chlorophyll, proline and essential oil content were investigated. Analysis of variance showed that the effect of the environmental conditions (normal and heat stress) was significant on all physiological and biochemical traits with the exception of the essential oil content. The heat stress decreased physiological traits and total chlorophyll in comparison with the normal conditions but it had no significant effect on the essential oil content. Findings indicated that the application of exogenous salicylic acid improves essential oil content in chamomile cultivars under environmental heat stress conditions.
\end{abstract}

Keywords: German chamomile; essential oil; heat stress; salicylic acid; proline; chlorophyll

\section{Introduction}

Salicylic acid (SA) is a well-known endogenous plant signal molecule involved in biochemical pathways, disease resistance and many plant responses [1]. On the other hand, SA is a signaling molecule that regulates plant responses to heat stress and disease resistance. It can also change to increase heat-induced Hsp/Hsc70 accumulation in higher plants [2,3]. Salicylic acid is necessary 
for the establishment of systemic acquired resistance in plants [3]. Salicylic acid and jasmonates, through the expression of genes codifying toward enzymes involved in the biosynthesis of secondary metabolites, can increase plant cell productivity [4]. The influence of exogenous salicylic acid depends on various factors, including the concentration of salicylic acid, the developmental phase, the species and the method of application [1]. Lately, the impact of salicylic acid on the metabolic profile of Catharanthus roseus cell suspensions has been indicated [5]. Soluble phenolic compounds increase in chamomile plants by using salicylic acid [1]. Salicylic acid relieves the negative effect of oxidative stress and it improves $\mathrm{NaCl}$ stress tolerance parameters accompanying mineral nutrient contents in chamomile plants [6]. Chamomile is one of the most crucial medicinal plants in the world which has many utilizations in the food, pharmaceutical, hygienic and cosmetic industries. Botanically, chamomile is an annual plant, belonging to the Asteraceae family and indigenous to Iran, and it grows as a wild plant in Europe [7,8]. Chamomile is naturally dispersed in the south, southwest, west and northwest of Iran and its utilization has a long history in Iranian traditional medicine [9]. Chamomile may be examined as an economical crop for fields with high temperature and water rareness due to its sizeable adaptability to a large spectrum of soils and weather conditions $[10,11]$. Rowshan and Bahmanzadegan (2013) reported that the the application of exogenous salicylic acid with 200 and $400 \mathrm{mg} \cdot \mathrm{L}^{-1}$ concentrations may modify secondary metabolites and their pathway by impacts on plastids, the chlorophyll level and representing stress conditions. The stress produced by SA modifies the quality and quantity of the essential oil of yarrow (Achillea millefolium) [12]. The content and compounds of essential oil are different in the chamomile flower and they depend on genotype, and environmental factors such as light intensity, day length, temperature, habitat, management of production and post-harvest processes [13,14]. Variations in oil content and composition have been reported in essential oil-bearing plants such as basil and Artemisia under water stress conditions [10,15]. In chamomile, the effects of cropping techniques, planting date, genotypes and ecological conditions on the yield of essential oil and the oil composition have been considered [10,16]. Farhoudi et al. (2012) indicated that medium drought stress increased the oil yield [9]. D'Andrea (2002) reported that there were no statistical differences on the essential oil percentage among the four chamomile cultivars grown in southern Italy [17]. Jeshni et al. (2014) indicated that drought stress caused significant effects on physiological traits, essential oil yield and essential oil components. The essential oil components increased whereas the essential oil yield decreased in response to severe drought stress [8]. In contrast, heat stress has been known as an agricultural problem in many regions in the world. High temperature produces a series of physiological and biochemical modifications in plants, which influence plant growth and development and can lead to severe diminution in economic yield [18-20]. Plants need to acquire thermotolerance against the adverse effect of high temperature. Heat stress damages plant cells and produces osmotic and oxidative stresses [21]. It was shown that the drought stress decreased the physiological parameters and apigenin content in German chamomile but it had no significant effect on the essential oil content [10]. Razmjoo et al. (2008) expressed that increased salinity caused a significant reduction in the plant height, and fresh and dry flower weight of chamomile plants. Also, drought caused a significant reduction in the fresh and dry flower weight and essential oil content of chamomile [15]. The physiological and biochemical traits including proline, photosynthetic pigments (chlorophyll A, B and carotenoids), glutamine synthetase (GS), betaine, ascorbate peroxidase (AOX), soluble proteins, glycine and mineral elements were examined in many plants such as rice, pepper and cabbages under heat stress, salinity, drought and water deficiency conditions $[22,23]$. For heat tolerance screening in plant breeding programs, the biochemical and physiological parameters were evolved efficiently under heat stress or drought conditions [19]. Heidari and Sarani (2012) reported that the proline and soluble carbohydrates increased in chamomile leaves under iron deficit and salinity treatments [22]. The proline level and antioxidative activity of Indian mustard (Brassica juncea L.) reduced significantly in response to salicylic acid under heat stress, but the plants subjected to high temperature showed a significant reduction in growth, photosynthesis traits and chlorophyll content [24]. The purpose of this investigation was to examine the influence 
of the exogenous application of salicylic acid concentrations on the physiological and biochemical parameters and essential oil content of chamomile (Matricaria chamomilla L.) under normal and heat stress conditions.

\section{Material and Methods}

\subsection{Experimental Site Description}

Two factorial field experiments were performed using a randomized complete block design (RCBD) with three replications at the experimental farm of Bushehr Research Center for Agriculture and Natural Resources, Borazjan, Iran, during the 2011-2012 season. The geographical coordinates of the experiment site was $29^{\circ} 12^{\prime} 21^{\prime \prime} \mathrm{N}, 51^{\circ} 15^{\prime} 07^{\prime \prime} \mathrm{E}$, with altitude of $110 \mathrm{~m}$. The chemical and physical properties of soil and water of the experimental location are presented in Tables 1-3. The chamomile seeds were provided by the seed bank of the Medicinal Plants and Drugs Research Institute, Shahid Beheshti University, Tehran, Iran. Each experimental plot size was $1 \mathrm{~m} \times 1 \mathrm{~m}$ and in each plot, the plants were grown in three equidistant rows with adjacent rows being $30 \mathrm{~cm}$ apart. In each plot, $20 \mathrm{~g}$ of ammonium nitrate fertilizer was used before planting date in addition to another $20 \mathrm{~g}$ being applied one month hence. Each experimental site had 45 plots (including 15 plots in each block) and totally the two experiments had 90 plots. The distance between the two main plots or experimental sites was seven meters. The seeds were sown superficially by hand and then were covered through a very thin layer of sandy soil.

Table 1. Chemical characteristics for soil of experimental field before implementation of experiment.

\begin{tabular}{|c|c|c|c|c|c|c|c|c|c|c|}
\hline $\begin{array}{l}\text { Soil Depth } \\
\text { (cm) }\end{array}$ & $\begin{array}{c}E C \\
\left(\mathrm{ds} \cdot \mathrm{m}^{-1}\right)\end{array}$ & $\mathrm{pH}$ & $\begin{array}{c}\text { T.N.V * } \\
\text { (\%) }\end{array}$ & $\begin{array}{c}\text { O.C }{ }^{* *} \\
(\%)\end{array}$ & $\mathrm{Ca}^{2+}+\mathrm{Mg}^{2+}$ & $\mathrm{Na}^{+}$ & $\mathrm{Cl}^{-}$ & $\mathrm{HCO}_{3}{ }^{-}$ & $\mathrm{SO}_{4}^{-}$ & SAR \\
\hline \multirow{2}{*}{$0-30$} & \multirow{2}{*}{6.3} & \multirow{2}{*}{7.8} & \multirow{2}{*}{60} & \multirow{2}{*}{0.33} & \multicolumn{6}{|c|}{ meq/L } \\
\hline & & & & & 58 & 25 & 20 & 4 & 59 & 4.6 \\
\hline
\end{tabular}

Table 2. Chemical properties for irrigation water of experiment.

\begin{tabular}{|c|c|c|c|c|c|c|c|}
\hline \multirow{2}{*}{$\mathrm{EC}\left(\mathrm{ds} \cdot \mathrm{m}^{-1}\right)$} & \multirow{2}{*}{$\mathrm{pH}$} & $\mathrm{HCO}_{3}^{-}$ & $\mathrm{Cl}^{-}$ & $\mathrm{SO}_{4}^{-}$ & $\mathrm{Ca}^{2+}+\mathrm{Mg}^{2+}$ & $\mathrm{Na}^{+}$ & SAR \\
\hline & & \multicolumn{6}{|c|}{ meq. $\mathrm{L}^{-1}$} \\
\hline 3.7 & 7.6 & 4.5 & 8.5 & 36 & 37 & 12 & 2.8 \\
\hline
\end{tabular}

Table 3. Physical characteristics for soil of experimental field before implementation of experiment.

\begin{tabular}{|c|c|c|c|c|c|c|c|c|c|}
\hline $\begin{array}{l}\text { Soil } \\
\text { Depth } \\
\text { (cm) }\end{array}$ & $\begin{array}{l}\text { Bulk } \\
\text { Density } \\
\mathrm{g} \cdot \mathrm{cm}^{-1}\end{array}$ & $\begin{array}{l}\text { Humidity } \\
(\% / w) \text { in } \\
\text { F.C Status }\end{array}$ & $\begin{array}{l}\text { Humidity } \\
(\% / w) \text { in } \\
\text { P.W.P } \\
\text { Status }\end{array}$ & $\begin{array}{l}\text { Particle } \\
\text { Density } \\
\mathrm{g} \cdot \mathrm{cm}^{-1}\end{array}$ & $\begin{array}{l}\text { The Average } \\
\text { of Penetration } \\
\text { Rate }\left(\mathrm{cm} \cdot \mathrm{h}^{-1}\right)\end{array}$ & $\begin{array}{l}\text { Moment } \\
\text { Penetration } \\
\text { Rate } \\
\left(\mathrm{cm} \cdot \mathrm{h}^{-1}\right)\end{array}$ & $\begin{array}{l}\text { Saturation } \\
\text { Percent }\end{array}$ & Texture & $\begin{array}{l}\text { Clay } \\
\text { Percent }\end{array}$ \\
\hline $30-60$ & 1.43 & 15.4 & 6.5 & 2.65 & & & & & \\
\hline 60-90 & 1.43 & 13.3 & 7.2 & 2.65 & & & & & \\
\hline
\end{tabular}

\subsection{Plants Growth and Air Temperature}

To evaluate the impact of high temperature (heat stress) on growth, development and yield of plants under field conditions, several different locations in the hot zones, different sowing dates in hot areas and/or controllable growth chambers [25-29] are utilized. Hence, in this study, high temperature treatment was conducted under field (real) conditions in a very hot area in the southwest of Iran by changing sowing date (late planting date). The seeds of chamomile cultivars (Bushehr (diploid), Bona (diploid) and Bodegold (tetraploid)) were planted on two different sowing dates corresponding to optimum planting date (24 December 2011) and late planting date (7 February 2012). The late sowing 
date (as the heat stress treatment) was set up so that more vegetative stages and complete flowering period were meet with high temperature at the end of agronomic season in Bushehr province. The meteorological conditions during the experimental year (2011-2012) for growth and development of chamomile are presented in Table 4.

Table 4. Meteorological data during the experimental year (2011-2012) for growth and development of chamomile in Borazjan, Bushehr Province, Iran.

\begin{tabular}{|c|c|c|c|c|c|c|c|}
\hline \multirow{2}{*}{$\begin{array}{l}\text { Month and } \\
\text { Year }\end{array}$} & \multicolumn{2}{|c|}{$\begin{array}{c}\text { Average of } \\
\text { Temperature }\left({ }^{\circ} \mathrm{C}\right)\end{array}$} & \multicolumn{2}{|c|}{$\begin{array}{c}\text { Average of Relative } \\
\text { Humidity }(\%)\end{array}$} & \multirow{2}{*}{$\begin{array}{l}\text { Precipitation } \\
\quad(\mathrm{mm})\end{array}$} & \multirow{2}{*}{$\begin{array}{l}\text { Average of Sunny } \\
\text { Hours (h) }\end{array}$} & \multirow{2}{*}{$\begin{array}{l}\text { Evaporation } \\
(\mathrm{mm})\end{array}$} \\
\hline & Min & Max & Min & Max & & & \\
\hline November 2011 & 17.8 & 30.6 & 27 & 60 & 39.4 & 7.4 & 5.3 \\
\hline December 2011 & 10.2 & 21.4 & 45 & 82 & 62.2 & 8 & 2.9 \\
\hline January 2012 & 10.6 & 22 & 42 & 76 & 32.1 & 6.7 & 2.9 \\
\hline February 2012 & 10.1 & 21 & 39 & 77 & 33.8 & 5.7 & 3.4 \\
\hline March 2012 & 10.9 & 24.1 & 29 & 69 & 22.1 & 6.8 & 5.2 \\
\hline April 2012 & 18.1 & 31.8 & 21 & 64 & 10.2 & 6.6 & 8.8 \\
\hline May 2012 & 25.7 & 40.6 & 12.2 & 34 & 0 & 7.3 & 11.3 \\
\hline June 2012 & 28.2 & 44.1 & 13 & 36 & 0 & 10 & 14.2 \\
\hline
\end{tabular}

\subsection{Salicylic Acid Treatments}

Salicylic acid concentrations including five levels ( 0 (control), 1, 10, 25 and $100 \mathrm{mg} \cdot \mathrm{L}^{-1}$ ) were prepared and used on three German chamomile cultivars (Bushehr (diploid), Bona (diploid) and Bodegold (tetraploid). The salicylic acid was purchased from Merck Co. (Darmstadt, Germany). Foliar spray using salicylic acid was scheduled during the growing and flowering stages of chamomile plants. The salicylic acid treatments were applied three times during vegetative and reproductive phases at every 15 days. The first stage of salicylic acid foliar spray was at 60 days after planting. The spray was done at 10 a.m. until 2 p.m. for each treatment and plot. All spray solutions were applied to the shoots uniformly using a hand pump sprayer. Precise dates of foliar spraying using salicylic acid solutions are presented in Table 5.

Table 5. Spraying dates of chamomile by salicylic acid under normal and heat stress conditions.

\begin{tabular}{ccc}
\hline \multirow{2}{*}{ Time of Spraying } & \multicolumn{2}{c}{ Environmental Conditions } \\
\cline { 2 - 3 } & Normal & Heat Stress \\
\hline 1 & 21 February 2012 & 8 April 2012 \\
2 & 8 March 2012 & 23 April 2012 \\
3 & 22 March 2012 & 8 May 2012 \\
\hline
\end{tabular}

\subsection{Physiological Characteristics}

The evaluated physiological characters included plant height $(\mathrm{cm})$, capitol diameter $(\mathrm{mm})$, 1000 grain weight $(\mathrm{g})$, fresh flower weight $(\mathrm{g})$ and dried flower weight $(\mathrm{g})$. The plant height was calculated at full bloom period as a mean height of 10 plants in each plot using meter. After each harvest samples were weighed $( \pm 0.001 \mathrm{~g})$ using balance set and after drying at room temperature $\left(20-25{ }^{\circ} \mathrm{C}\right)$ dried flower weight of each plot was calculated. The flower capitol diameter was measured at full bloom period as a mean capitol diameter of 15 flowers in each plot by using digital caliper. The 1000 grain weight trait was calculated using seed counter device and digital balance. The chamomile flowering was initiated in early March 2012 and it continued until end of May 2012. Thus, the harvest was carried out every seven to 10 days for each plot. The number of harvests and its dates are presented in the Table 6. 
Table 6. Harvest times of chamomile cultivars under normal and heat stress conditions.

\begin{tabular}{ccccccc}
\hline \multicolumn{7}{c}{ Environmental Conditions } \\
\hline $\begin{array}{c}\text { Normal } \\
\text { Harvest }\end{array}$ & $\begin{array}{c}\text { Bushehr } \\
\text { Cultivar }\end{array}$ & $\begin{array}{c}\text { Bona } \\
\text { Cultivar }\end{array}$ & $\begin{array}{c}\text { Bodegold } \\
\text { Cultivar }\end{array}$ & $\begin{array}{c}\text { Bushehr } \\
\text { Cultivar }\end{array}$ & $\begin{array}{c}\text { Bona } \\
\text { Cultivar }\end{array}$ & $\begin{array}{c}\text { Bodegold } \\
\text { Cultivar }\end{array}$ \\
\hline 1 & 27 Mar 2012 & 19 Apr 2012 & 28 Apr 2012 & 22 Apr 2012 & 04 May 2012 & 31 May 2012 \\
2 & 07 Apr 2012 & 29 Apr 2012 & 08 May 2012 & 03 May 2012 & 14 May 2012 & - \\
3 & 19 Apr 2012 & 08 May 2012 & 14 May 2012 & 13 May 2012 & 31 May 2012 & - \\
4 & 29 Apr 2012 & 14 May 2012 & - & 31 May 2012 & - & - \\
5 & 14 May 2012 & - & - & - & - & - \\
\hline
\end{tabular}

\subsection{Chlorophyll Measurement}

In order to estimate the total chlorophyll, leaf samples were collected and dried for $48 \mathrm{~h}$ at a temperature of $75{ }^{\circ} \mathrm{C}$. The amount of chlorophyll was estimated according to the method of Lichtenthaler et al. (1987) [30].

\subsection{Determination of Free Proline Concentration}

Free proline content was determined according to a modified method of Bates et al. (1973) [31], in dried leaf samples which were homogenized in $5 \mathrm{~mL}$ of sulphosalycylic acid (3\%) by using mortar and pestle. To $2 \mathrm{~mL}$ of extract in a test tube, $2 \mathrm{~mL}$ of glacial acetic acid and $2 \mathrm{~mL}$ of ninhydrin reagent were added. The mixture was boiled in a water bath at $100^{\circ} \mathrm{C}$ for $30 \mathrm{~min}$ and then allowed to cool. After that, $6 \mathrm{~mL}$ of toluene were added and the combination transferred to a separating funnel. After thorough mixing, the chromophore-containing toluene was separated and the absorbance read at $520 \mathrm{~nm}$ in a spectrophotometer against a toluene blank. Finally, the concentration of proline was calculated using a standard curve $[22,32]$.

\subsection{Extraction of Essential Oil}

The essential oil of air-dried flower of chamomile ( $30 \mathrm{~g})$ was isolated by hydrodistillation for $5 \mathrm{~h}$, using a Clevenger-type apparatus in $500 \mathrm{~mL}$ round-bottom flask with $300 \mathrm{~mL}$ distillated water according to the method described in British Pharmacopeia [10]. The essential oil was stored in dark glass bottles and then dried over anhydrous sodium sulphate $\left(\mathrm{Na}_{2} \mathrm{SO}_{4}\right)$. Finally, the essential oil was kept in refrigerator $\left(4^{\circ} \mathrm{C}\right)$ until they were analyzed [33].

\subsection{Data Analysis}

After physiological and biochemical evaluation, statistical analyses were performed by using MSTAT-C and SAS System Software version 6.12 [34]. Data were analyzed by combined analysis of variance and the mean results were compared by using Duncan's multiple range test. Data were converted when necessary before analysis to satisfy suppositions of normality and homoscedasticity.

\section{Results and Discussion}

\subsection{Plant Height}

The analysis of variance showed that the plant height was significantly influenced by environmental conditions and chamomile cultivars (Table 7). The interaction between environmental conditions and cultivars was significant (Table 8), while the effect of SA treatment was not significant on the plant height trait. Duncan analysis for the interaction between cultivars and environmental conditions showed that the Bodegold cultivar had the highest plant height with an average of $64.41 \mathrm{~cm}$ under normal conditions. In contrast, the Bushehr cultivar had the lowest plant height with an average of $22.01 \mathrm{~cm}$ under heat stress conditions. Meanwhile, the Bona cultivar with a height average of $60.04 \mathrm{~cm}$ in comparison with the Bodegold cultivar had no significant differences under normal 
conditions (Table 8). The Bodegold and Bona cultivars had the greatest plant height with averages of $64.41 \mathrm{~cm}$ and $60.04 \mathrm{~cm}$, respectively. These cultivars showed $35.9 \mathrm{~cm}$ and $12.34 \mathrm{~cm}$ reductions, respectively, in the plant height trait under heat stress conditions, while the Bushehr cultivar underwent a $12.07 \mathrm{~cm}$ reduction in the plant height trait under the same conditions. D'Andrea (2002) showed that the tetraploid cultivars of German chamomile in comparison with the diploid cultivars had greater plant height [17]. Alexandra (2005) reported that the Bona cultivar in comparison with the Goral and Lutea cultivars had a higher plant height [35]. Baghalian et al. (2010) reported that drought stress decreased the chamomile plant height [10]. Farhoudi et al. (2012) illustrated that severe drought caused substantial reductions in the plant height of chamomile [9]. Razmjoo et al. (2008) indicated that drought stress caused a significant reduction in the plant height of chamomile [15]. The reduction in plant height seems to be the result of disturbed plant water relations, in particular the turgor potential [36]. This means that reduced water uptake results in a decrease in the tissue water contents and turgor. Therefore, under heat stress conditions, cell elongation in plants is inhibited by reduced turgor pressure. In addition, heat stress also trims down the photo-assimilation and required metabolites for cell division. As a consequence, impaired mitosis, cell elongation and expansion result in reduced plant height and growth [10,37]. These findings showed that the chamomile tetraploid cultivar had a higher plant height under normal conditions in comparison with the diploid cultivars. Also, the severe heat stress reduced the plant height in the tetraploid cultivar in particular. This is in accordance with results of D'Andrea (2002) [17].

\subsection{Capitol Diameter}

The analysis of variance indicated that the capitol diameter trait was significantly influenced by environmental conditions and the cultivar at the statistical level $(p \leqslant 0.01)$ (Table 7). The interaction between environmental conditions and cultivars also was significant at the statistical level $(p \leqslant 0.01)$. The mean comparison for the interaction between environmental conditions and cultivars showed that the Bodegold cultivar had the highest capitol diameter with an average of $8.94 \mathrm{~mm}$ under normal conditions. In contrast, the Bushehr cultivar had the lowest capitol diameter with an average of $6.43 \mathrm{~mm}$ under normal conditions, although the Bodegold cultivar showed a $2.08 \mathrm{~mm}$ reduction in the capitol diameter trait under heat stress conditions (Table 8). Alexander (2005), in an investigation on the morphological and chemical characteristics of chamomile, reported that the highest capitol diameter belonged to tetraploid cultivars [35]. Circella et al. (1993), in a study on the morphological traits of different genotypes of chamomile in southern Italy, observed that the tetraploid cultivars had the highest capitol diameter [38]. D'Andrea (2002), in research on the diversity of four tetraploid and diploid cultivars based on morphological characteristics, reported the highest capitol diameter for tetraploid cultivars in southern Italy [17]. Razmjoo et al. (2008) found that increasing the salinity stress caused a reduction in the number of branches per plant, the head diameter, the peduncle length and the flowers per plant. Also, drought caused a significant reduction in the head diameter [15]. In the present research, the capitol diameter of the tetraploid cultivar was greater than the diploid cultivars and also it was reduced under the heat stress conditions in contrast with the normal conditions. Therefore, these results confirm previous research regarding the negative effect of abiotic stress on morphological traits in plants.

\subsection{The 1000 Grain Weight}

The analysis of variance demonstrated that the 1000 grain weight was significantly influenced by the environmental conditions and the interaction of the environmental conditions and cultivars at the statistical level $(p \leqslant 0.01)$ (Table 7). The mean comparison of the interaction between environmental conditions and cultivars indicated that the Bona cultivar had the highest 1000 grain weight with an average of $0.056 \mathrm{~g}$ under normal conditions. In contrast, the Bona cultivar had the lowest 1000 grain weight with an average of $0.035 \mathrm{~g}$ under heat stress conditions (Table 8). The Bona cultivar showed a 0.021 g reduction in the 1000 grain weight under severe heat stress. Modarresi et al. (2010) 
reported that the 1000 grain weight decreased in wheat under heat stress in comparison with normal conditions [26]. In a similar experiment, Mohammadi et al. (2007) demonstrated that the 1000 grain weight diminished in wheat as a consequence of heat stress under controlled greenhouse conditions [25]. Ayeneh et al. (2002) showed that the 1000 grain weight decreased extremely in wheat under natural heat stress at the end of the agronomic season [28]. The main reason for the reduction of the 1000 grain weight in chamomile plants may be attributed to genotypes and the effect of heat stress during grain filling [28].

\subsection{Fresh Flower Weight}

The analysis of variance showed that the fresh flower weight was significantly influenced by the interaction between the environmental conditions and cultivars at the statistical level $(p \leqslant 0.01)$. The fresh flower weight was also significantly influenced by the interactions of the environmental conditions $\times$ cultivars and the environmental conditions $\times$ salicylic acid (Table 7). Duncan analysis for the interaction between environmental conditions and cultivars showed that the Bona cultivar produced the highest fresh flower weight with an average of $260.42 \mathrm{~g} \cdot \mathrm{m}^{-2}$ under normal conditions. In contrast, the Bodegold cultivar produced the lowest fresh flower weight with an average of $11.85 \mathrm{~g} \cdot \mathrm{m}^{-2}$ under heat stress conditions (Table 8 ). The mean comparison for the interaction between environmental conditions and salicylic acid indicated that the highest fresh flower weight was obtained with an average of $287.97 \mathrm{~g} \cdot \mathrm{m}^{-2}$ at the concentration of $1 \mathrm{mg} \cdot \mathrm{L}^{-1} \mathrm{SA}$ under normal conditions. In contrast, the lowest fresh flower weight reached was an average of $83.09 \mathrm{~g} \cdot \mathrm{m}^{-2}$ at the concentration of $25 \mathrm{mg} \cdot \mathrm{L}^{-1} \mathrm{SA}$ under heat stress conditions (Table 9). Razmjoo et al. (2008) reported that increased salinity caused a significant reduction in the fresh and dry flower weight. Also, drought caused a significant reduction in the fresh and dry flower weight [15]. On the other hand, Baghalian et al. (2010) reported that drought stress decreased the flower yield and shoot weight [10]. D'Andrea (2002) reported that the chamomile diploid cultivars had the highest dried and fresh flower weight [17]. Circella et al. (1993) observed that the chamomile diploid cultivars had the greatest flower yield and 100 flower weight [38]. In the present research, the Bona cultivar (diploid) produced the greatest dried and fresh flower weight under normal and heat stress conditions, which is in a good agreement with the results of D'Andrea (2002) and Golparvar et al. (2011) [17,39]. 
Table 7. Combined analysis of variance for studied traits of German chamomile.

\begin{tabular}{|c|c|c|c|c|c|c|c|c|c|}
\hline \multicolumn{10}{|c|}{ Mean Square (MS) } \\
\hline S.O.V & DF & $\begin{array}{l}\text { Plant Height } \\
\text { (cm) }\end{array}$ & $\begin{array}{c}\text { Capitol } \\
\text { Diameter }(\mathrm{mm})\end{array}$ & $\begin{array}{l}\text { Fresh Flower } \\
\text { Weight (g) }\end{array}$ & $\begin{array}{l}\text { Dried Flower } \\
\text { Weight (g) }\end{array}$ & $\begin{array}{l}1000 \text { Grain } \\
\text { Weight (g) }\end{array}$ & $\begin{array}{l}\text { Total Chlorophyll } \\
(\mu \mathrm{g} / \mathrm{g} \cdot \mathrm{dw})\end{array}$ & $\begin{array}{c}\text { Proline } \\
(\mu \mathrm{mol} / \mathrm{g} \cdot \mathrm{dw})\end{array}$ & $\begin{array}{c}\text { Essential Oil\% } \\
(w / w)\end{array}$ \\
\hline EC & 1 & $9098.47 * *$ & $10.51 * *$ & 241064.95 ** & $14175.22 * *$ & $0.0024 * *$ & $19337.71^{* *}$ & 15090.63 ** & $0.0008 \mathrm{~ns}$ \\
\hline Block & 4 & 19.98 & 0.04 & 6602.1 & 328.69 & 0.00015 & 18.32 & 165.45 & 0.0001 \\
\hline Cult & 2 & 5303.06 ** & $9.22 * *$ & $171402.77^{* *}$ & $9794.01 * *$ & $0.00022 \mathrm{~ns}$ & $130.21 * *$ & 3423.70 ** & $0.0006 \mathrm{~ns}$ \\
\hline SA & 4 & $68.18 \mathrm{~ns}$ & $0.24 \mathrm{~ns}$ & $18051.77^{*}$ & $1080.04 * *$ & $0.00008 \mathrm{~ns}$ & $10.61 \mathrm{~ns}$ & $116.75 \mathrm{~ns}$ & $0.0004 \mathrm{~ns}$ \\
\hline Cult $\times$ SA & 8 & $12.66 \mathrm{~ns}$ & $0.10 \mathrm{~ns}$ & $1750.12 \mathrm{~ns}$ & $71.85 \mathrm{~ns}$ & $0.0001 \mathrm{~ns}$ & $32.82 \mathrm{~ns}$ & $222.09 *$ & $0.0001 \mathrm{~ns}$ \\
\hline $\mathrm{EC} \times$ Cult & 2 & $1406.06 * *$ & $15.29 * *$ & $34884.14 * *$ & 1031.30 * & $0.00064^{* *}$ & $29.77 \mathrm{~ns}$ & $9070.7 * *$ & 0.0023 ** \\
\hline $\mathrm{EC} \times \mathrm{SA}$ & 4 & 89.27 ns & $0.15 \mathrm{~ns}$ & $28412.84 * *$ & $1124.1^{* *}$ & $0.0001 \mathrm{~ns}$ & $1.46 \mathrm{~ns}$ & $10.60 \mathrm{~ns}$ & $0.0002 \mathrm{~ns}$ \\
\hline $\mathrm{EC} \times$ Cult $\times \mathrm{SA}$ & 8 & $29.75 \mathrm{~ns}$ & $0.17 \mathrm{~ns}$ & $6359.83 \mathrm{~ns}$ & $323.79 \mathrm{~ns}$ & $0.0001 \mathrm{~ns}$ & $9.26 \mathrm{~ns}$ & $216.25 *$ & $0.0001 \mathrm{~ns}$ \\
\hline Error & 56 & 35.41 & 6.79 & 6656.86 & 290.1 & 0.000085 & 23.91 & 105.41 & 0.0003 \\
\hline C.V & & 13.9 & 4.8 & 51.9 & 45.06 & 18.9 & 24.2 & 34.7 & 19.7 \\
\hline
\end{tabular}

EC (environmental conditions), Cult (cultivar), SA (salicylic acid), symbol $\left(^{*}\right)$ and $\left(^{* *}\right)$ : indicates statistically significant differences between treatments at $(p \leqslant 0.05)$ and $(p \leqslant 0.01)$ levels, respectively, as well as the letters (ns): shows statistically non-significant differences between treatments.

Table 8. Mean comparison of the interaction of environmental conditions $\times$ cultivar on studied characteristics of German chamomile.

\begin{tabular}{|c|c|c|c|c|c|c|c|c|}
\hline Characteristics & & & & & & & & \\
\hline $\begin{array}{l}\text { Environmental } \\
\text { Conditions }\end{array}$ & Cultivar & Plant Height (cm) & $\begin{array}{l}\text { Capitol Diameter } \\
(\mathrm{mm})\end{array}$ & $\begin{array}{c}\text { Fresh Flower } \\
\text { Weight }\left(\mathrm{gr} \cdot \mathrm{m}^{-2}\right)\end{array}$ & $\begin{array}{c}\text { Dried Flower } \\
\text { Weight }\left(\mathrm{gr} \cdot \mathrm{m}^{-2} \text { ) }\right.\end{array}$ & $\begin{array}{l}1000 \text { Grain } \\
\text { Weight (g) }\end{array}$ & $\begin{array}{c}\text { Proline } \\
(\mu \mathrm{mol} / \mathrm{g} \cdot \mathrm{dw})\end{array}$ & $\begin{array}{c}\text { Essential Oil \% } \\
(w / w)\end{array}$ \\
\hline \multirow{3}{*}{ Normal } & Bushehr & $34.08 \mathrm{c}$ & $7.18 \mathrm{~b}$ & 181.75ab & $42.06 \mathrm{ab}$ & $0.052 a$ & $24.76 \mathrm{~b}$ & $0.77 \mathrm{~d}$ \\
\hline & Bona & $60.04 a$ & $6.82 \mathrm{bc}$ & $260.42 \mathrm{a}$ & $65.63 a$ & $0.056 a$ & $10.96 \mathrm{c}$ & $0.82 \mathrm{c}$ \\
\hline & Bodegold & $64.41 \mathrm{a}$ & $8.94 a$ & $184.42 \mathrm{ab}$ & $43.33 \mathrm{ab}$ & $0.054 a$ & $14.26 \mathrm{c}$ & $1.23 \mathrm{a}$ \\
\hline \multirow{3}{*}{ Heat stress } & Bushehr & $22.01 \mathrm{~d}$ & $6.43 c$ & $79.99 \mathrm{bc}$ & $19.05 b c$ & $0.049 \mathrm{ab}$ & $15.80 \mathrm{c}$ & $0.89 \mathrm{~b}$ \\
\hline & Bona & $47.70 \mathrm{~b}$ & 7.59ab & $224.22 \mathrm{ab}$ & $51.08 \mathrm{a}$ & $0.035 \mathrm{~b}$ & $71.56 a$ & $0.76 \mathrm{de}$ \\
\hline & Bodegold & $28.49 \mathrm{~cd}$ & $6.86 \mathrm{bc}$ & $11.85 \mathrm{c}$ & $5.60 \mathrm{c}$ & $0.046 \mathrm{ab}$ & $40.31 \mathrm{~b}$ & $0.74 \mathrm{e}$ \\
\hline
\end{tabular}




\subsection{Dried Flower Weight}

The analysis of variance indicated that the dried flower weight was significantly influenced by the environmental conditions, salicylic acid and cultivar $(p \leqslant 0.01)$ (Table 7). The interaction between the environmental conditions and cultivars had a significant effect on the dried flower weight $(p \leqslant 0.05)$. In addition, the interaction between the environmental conditions and the salicylic acid had a significant effect on the dried flower weight $(p \leqslant 0.01)$ (Table 7). The means comparison of the interaction between the environmental conditions and cultivars showed that the Bona cultivar had the highest dried flower yield with averages of 65.63 and $51.08 \mathrm{~g} \cdot \mathrm{m}^{-2}$ under normal and heat stress conditions, respectively. Also, the Bodegold cultivar had the lowest dried flower yield with an average of $5.60 \mathrm{~g} \cdot \mathrm{m}^{-2}$ under heat stress conditions (Table 8). Duncan analysis for the interaction between the environmental conditions and salicylic acid showed that the highest dried flower weight obtained was an average of $67.66 \mathrm{~g} \cdot \mathrm{m}^{-2}$ at the concentration of $1 \mathrm{mg} \cdot \mathrm{L}^{-1} \mathrm{SA}$ under normal conditions. In contrast, the lowest dried flower weight obtained was an average of $21.45 \mathrm{~g} \cdot \mathrm{m}^{-2}$ at the concentration of $25 \mathrm{mg} \cdot \mathrm{L}^{-1} \mathrm{SA}$ under heat stress conditions (Table 9). Taviana (2001) and D'Andrea (2002) reported the highest dried and fresh flower yields in chamomile diploid cultivars [17,40]. Farhoudi et al. (2012) showed that severe drought caused substantial reductions in the shoot and flower dry weight of chamomile [9]. Razmjoo et al. (2008) indicated that increased salinity and drought stress caused a significant reduction in the fresh and dry flower weight [15]. In this study, the Bona cultivar (diploid) had the highest dried flower weight which is in accordance with the results of D'Andrea (2002) and Golparvar et al. (2011) [17,39].

Table 9. Mean comparison for the interaction between environmental conditions and salicylic acid on studied traits of chamomile.

\begin{tabular}{|c|c|c|c|}
\hline \multirow[b]{2}{*}{$\begin{array}{l}\text { Environmental } \\
\text { Conditions }\end{array}$} & \multirow[b]{2}{*}{$\begin{array}{l}\text { SA Concentration } \\
\left(\mathrm{mg} \cdot \mathrm{L}^{-1}\right)\end{array}$} & \multicolumn{2}{|c|}{ Traits } \\
\hline & & $\begin{array}{l}\text { Fresh Flower Weight } \\
\left(\mathrm{g} \cdot \mathrm{m}^{-2}\right)\end{array}$ & $\begin{array}{l}\text { Dried Flower Weight } \\
\left(\mathrm{g} \cdot \mathrm{m}^{-2}\right)\end{array}$ \\
\hline \multirow{5}{*}{ Normal } & 0 & $122.42 b c$ & $30.82 b$ \\
\hline & 1 & $287.97 \mathrm{a}$ & $67.66 a$ \\
\hline & 10 & $188.53 \mathrm{abc}$ & $45.67 \mathrm{ab}$ \\
\hline & 25 & $176.31 \mathrm{ab}$ & $43.41 \mathrm{ab}$ \\
\hline & 100 & $269.09 \mathrm{ab}$ & $64.14 \mathrm{a}$ \\
\hline \multirow{5}{*}{ Heat Stress } & 0 & $140.10 \mathrm{abc}$ & $29.24 b$ \\
\hline & 1 & $107.64 \mathrm{c}$ & $27.20 \mathrm{~b}$ \\
\hline & 10 & $96.86 c$ & $23.18 b$ \\
\hline & 25 & $83.09 c$ & $21.45 b$ \\
\hline & 100 & $99.09 \mathrm{c}$ & $25.13 b$ \\
\hline
\end{tabular}

\subsection{Total Chlorophyll Content}

The analysis of variance showed that the total chlorophyll content was significantly affected by the environmental conditions and cultivars $(p \leqslant 0.01)$ (Table 7). The mean comparison for the total chlorophyll content was performed between two environmental conditions (normal and heat stress). A significant reduction in the total chlorophyll content was observed under heat stress in comparison with normal conditions. The total chlorophyll content averaged $34.90 \mu \mathrm{g} / \mathrm{g} \cdot \mathrm{dw}$ under normal conditions. In contrast, the content of the total chlorophyll attained was an average of $5.59 \mu \mathrm{g} / \mathrm{g} \cdot \mathrm{dw}$ under heat stress conditions. In fact, severe heat stress caused a $29.31 \mu \mathrm{g} / \mathrm{g} \cdot \mathrm{dw}$ reduction in the total chlorophyll content under heat stress conditions (Figure 1). The chlorophyll content declined under heat stress in comparison with normal conditions [41]. The reduction of chlorophyll content is one of the most important and effective factors in the plant photosynthetic capacity [42]. Therefore, the decrease of the vegetative characterizations is related to the reduction of the photosynthesis pigment capacity. El-Khallal et al. (2009) reported that the content of photosynthetic pigments (chlorophyll A and B, 
carotenoids and total pigments) was reduced significantly in leaves of stressed plants and was increased in brassinolide and salicylic acid-treated plants [43]. The application of SA prevents chlorophyll degradation in grapevine leaves under heat stress [44]. Rowshan and Bahmanzadegan (2013) reported that the application of exogenous salicylic acid with 200 and $400 \mathrm{mg} \cdot \mathrm{L}^{-1}$ concentrations may modify secondary metabolites of yarrow (Achillea millefolium) and its pathway by effects on plastids, the chlorophyll level and representing stress conditions [12]. Farhoudi et al. (2012) reported that severe drought caused significant reductions in chlorophyll A contents and on the photosynthesis rate of chamomile [9]. A number of reports illustrated that chlorophyll biosynthesis was reduced in plants subjected to high-temperature stress $[45,46]$. Lesser accumulation of chlorophyll in heat-stressed plants may be attributed to impaired chlorophyll synthesis or its accelerated degradation or a combination of both effects. The inhibition of chlorophyll biosynthesis under high-temperature regimes results from a destruction of numerous enzymes involved in the mechanism of chlorophyll biosynthesis [47]. As stated in the Introduction, the influence of exogenous salicylic acid depends on various factors, including the concentration of salicylic acid, the developmental phase, the species and the method of application [1]. The lack of effect of the salicylic acid on the chlorophyll content may be due to the high intensity of heat stress so that severe heat stress impairs plastid and chlorophyll structures and decreases the contributing effect of exogenous salicylic acid. Also, it can be attributed to different responses of chamomile cultivars to specific concentrations and/or certain ranges of exogenous salicylic acid. In addition, the lack of salicylic acid effects on the chlorophyll content can be associated with time and the stage of sampling for chlorophyll measurement in the field conditions.

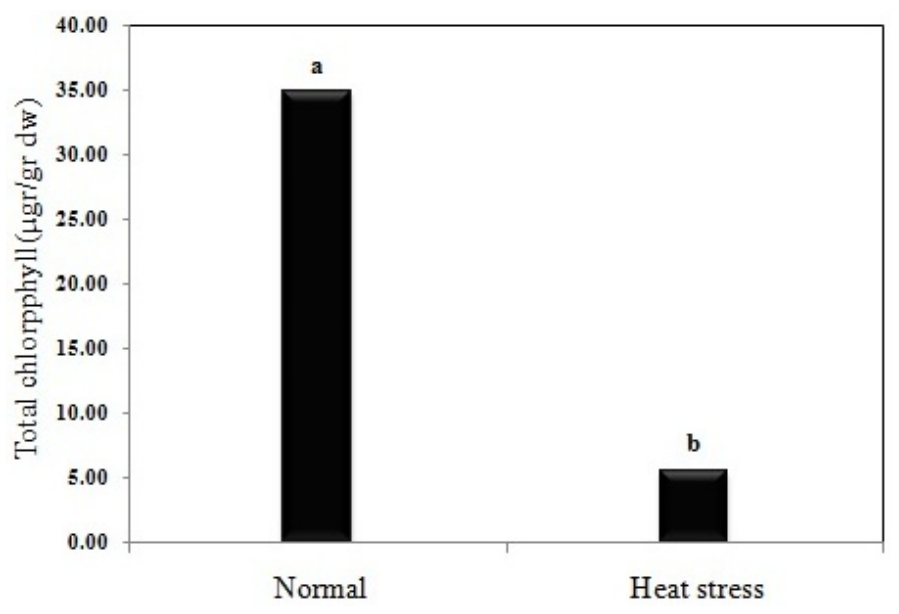

Figure 1. Comparison of the simple effect of normal and heat stress conditions on the total chlorophyll content in chamomile dried leaves.

\subsection{Free Proline Concentration}

The analysis of variance showed that the free proline concentration was significantly influenced by the environmental conditions and cultivars $(p \leqslant 0.01)$. The interaction of cultivar $\times$ salicylic acid and the triple interaction of environmental conditions $\times$ cultivar $\times$ salicylic acid had a significant effect on the free proline content $(p \leqslant 0.05)$. Also, the interaction of environmental conditions $\times$ cultivar had a significant effect on the proline content $(p \leqslant 0.05)$ (Table 7). The mean comparison for the interaction of environmental conditions $\times$ cultivar showed that the Bona cultivar had the highest leaf free proline content with an average of $71.56 \mu \mathrm{mol} / \mathrm{g} \cdot \mathrm{dw}$ under heat stress conditions. In contrast, the lowest amount of leaf free proline content belonged to the Bona cultivar with an average of $10.96 \mu \mathrm{mol} / \mathrm{g} \cdot \mathrm{dw}$ under normal conditions (Table 8). Duncan analysis for the triple interaction of environmental conditions $\times$ cultivar $\times$ salicylic acid on leaf free proline content indicated that the Bona cultivar had the highest amount of free proline content with an average of $91.96 \mu \mathrm{mol} / \mathrm{g} \cdot \mathrm{dw}$ in the control treatment under heat stress, whereas the Bona cultivar had the lowest amount of free proline content with an average of $7.96 \mu \mathrm{mol} / \mathrm{g} \cdot \mathrm{dw}$ at the concentration of $25 \mathrm{mg} \cdot \mathrm{L}^{-1} \mathrm{SA}$ under normal conditions (Table 10). 
Also, the Bona cultivar had the highest free proline content in comparison with the Bushehr and Bodegold cultivars with averages of $64.40,67.70,75.40$ and $58.36 \mu \mathrm{mol} / \mathrm{g} \cdot \mathrm{dw}$ at the concentrations of 1, 10, 25 and $100 \mathrm{mg} \cdot \mathrm{L}^{-1} \mathrm{SA}$ under heat stress, respectively. In contrast, the lowest free proline content belonged to the Bona cultivar with an average of $9.53,7.96$ and $10.06 \mu \mathrm{mol} / \mathrm{g} \cdot \mathrm{dw}$ at the concentration of 10, 25 and $100 \mathrm{mg} \cdot \mathrm{L}^{-1} \mathrm{SA}$ under normal conditions, respectively (Table 10). Kumar et al. (2012) reported that the proline content increased in wheat under heat stress conditions [32]. The antioxidative activity and proline level of Indian mustard (Brassica juncea L.) decreased significantly in response to salicylic acid under heat stress, but the plants subjected to high temperatures showed a significant reduction in growth, photosynthesis traits and chlorophyll [24]. Jeshni et al. (2014) showed that the proline content of chamomile increased in response to severe drought stress [8]. Farhoudi et al. (2012) showed that the proline, soluble carbohydrates and malondialdehyde contents of chamomile were increased under drought stress [9]. The proline is the most important substance to regulate the osmotic tension in higher plants under abiotic stresses such as salinity, drought, heat and cold [31]. The increase of the proline concentration is due to extensive protein degradation under abiotic stress such as drought (water deficit) and heat stress [19,48].

Table 10. Mean comparison of the interaction of environmental conditions $\times$ cultivar $\times$ salicylic acid on proline content according to $(\mu \mathrm{mol} / \mathrm{g} \cdot \mathrm{dw})$ of chamomile.

\begin{tabular}{ccccccc}
\hline \multicolumn{7}{c}{ SA Concentration $\left.\mathbf{( m g} \cdot \mathbf{L}^{-\mathbf{1}}\right)$} \\
\hline Environmental conditions & Cultivar & 0 & 1 & 10 & 25 & 100 \\
\hline \multirow{2}{*}{ Normal } & Bushehr & $34.73 \mathrm{~b}$ & $29.30 \mathrm{~b}$ & $20.30 \mathrm{c}$ & $20.06 \mathrm{c}$ & $26.56 \mathrm{bc}$ \\
& Bona & $13.13 \mathrm{c}$ & $14.23 \mathrm{~b}$ & $9.53 \mathrm{c}$ & $7.96 \mathrm{c}$ & $10.06 \mathrm{c}$ \\
& Bodegold & $11.70 \mathrm{c}$ & $11.93 \mathrm{~b}$ & $16.13 \mathrm{c}$ & $13.76 \mathrm{c}$ & $17.80 \mathrm{c}$ \\
\hline \multirow{2}{*}{ Heat Stress } & Bushehr & $13.30 \mathrm{c}$ & $22.96 \mathrm{~b}$ & $18.90 \mathrm{c}$ & $11.70 \mathrm{c}$ & $12.16 \mathrm{c}$ \\
& Bona & $91.96 \mathrm{a}$ & $64.40 \mathrm{a}$ & $67.70 \mathrm{a}$ & $75.40 \mathrm{a}$ & $58.36 \mathrm{a}$ \\
& Bodegold & $27.36 \mathrm{bc}$ & $47.80 \mathrm{a}$ & $41.50 \mathrm{~b}$ & $42.06 \mathrm{~b}$ & $42.83 \mathrm{ab}$ \\
\hline
\end{tabular}

\subsection{Essential Oil Content}

The analysis of variance showed that the essential oil content was significantly influenced by the interaction between environmental conditions and cultivars $(p \leqslant 0.01)$ (Table 7). The mean comparison of the interaction between environmental conditions and cultivars indicated that the Bodegold cultivar had the highest and lowest essential oil content with averages of $1.23 \%(w / w)$ and $0.74 \%(w / w)$ under normal and heat stress conditions, respectively (Table 8$)$. In addition, a mean comparison was carried out for essential oil content under normal and heat stress conditions separately (Tables 11 and 12). The results of the mean comparison for each experimental site separately showed that the highest essential oil content with an average of $0.126 \%(w / w)$ was found in the Bona cultivar at a concentration of $25 \mathrm{mg}$. $\mathrm{L}^{-1} \mathrm{SA}$ under normal conditions. In contrast, the lowest essential oil content with an average of $0.076 \%(w / w)$ was found in the Bushehr and Bodegold cultivars at concentrations of 0 and $1 \mathrm{mg} \cdot \mathrm{L}^{-1} \mathrm{SA}$ under normal conditions, respectively (Table 11). The mean comparison for essential oil content under heat stress conditions showed no significant differences (Table 12). Biosynthesis of secondary metabolites is not only controlled genetically but is also strongly affected by environmental parameters [10,16,49]. Salamon (2006) reported that the essential oil content was $0.24 \%$ to $2.0 \%$ in chamomile dried flowers and its essential oil color was blue to dark blue [14]. The essential oil extracted had a blue to dark blue color in the present study. This is may be related to the increase in secondary metabolites such as phenolics including flavonoids, anthocyanins, and plant steroids which are also significantly involved in plant responses under heat stress $[19,50]$. The compositions of essential oil were compared in Egyptian and Brazilian chamomile ecotypes. The essential oil percent was reported from $0.2 \%$ to $0.3 \%$ in Brazilian ecotypes and it was also reported at $0.5 \%$ in Egyptian chamomile ecotypes [51]. Rowshan and Bahmanzadegan (2013) reported that the the application of exogenous salicylic acid with 200 and $400 \mathrm{mg} \cdot \mathrm{L}^{-1}$ concentrations may modify secondary metabolites and their pathway by impacts on plastids, the chlorophyll level 
and representing stress conditions. The salicylic acid, like stress, manipulated the quality and quantity of the essential oil of yarrow (Achillea millefolium) [12]. D'Andrea (2002) reported that there were no statistical differences between the essential oil percentage among the four chamomile cultivars grown in southern Italy [17]. Jeshni et al. (2014) indicated that drought stress caused significant effects on physiological traits, essential oil yield and essential oil components. The essential oil components increased, whereas the essential oil yield decreased in response to severe drought stress [8]. Baghalian et al. (2010) indicated that drought stress had no significant effect on the oil content or oil composition [10]. Razmjoo et al. (2008) showed that the increased salinity and drought stress caused a significant reduction in the essential oil content [15]. The reduction in the essential oil content may be due to a disturbance in photosynthesis and carbohydrate production under stress conditions and suppression of the plant growth $[15,52]$. Changes in oil content and composition are reported in essential oil-bearing plants such as basil and Artemisia under water stress conditions [10,15]. Farhoudi et al. (2012) indicated that medium drought stress increased the oil yield [9]. In chamomile, the effects of cropping techniques, planting date, genotypes and ecological conditions on the yield of essential oil and oil composition have been considered [10,16]. Variation in essential oil content and composition in Iran is ascribed to the influence of agricultural practices, and environmental and genetic factors [53]. The essential oil content in chamomile plants depends on three groups of factors: genotype, weather, and agrotechnical factors [54]. The lack of the effect of salicylic acid on the essential oil content may be due to plant species and genotypes that have different responses to salicylic acid under environmental conditions. Moreover, it can be ascribed to changes in the secondary metabolites pathway by effects on the plastids and chlorophyll level under severe heat stress. Furthermore, it may be due to different responses of chamomile genotypes to specific concentrations and/or certain ranges of exogenous salicylic acid. It is probable that the salicylic acid concentrations applied in this experiment were not efficient against the acute heat stress. Generally, salicylic acid can influence the quality of chamomile essential oil.

Table 11. Mean comparison for essential oil $\%(w / w)$ of chamomile treated with salicylic acid under normal conditions.

\begin{tabular}{cccccc}
\hline \multirow{2}{*}{ Cultivar } & \multicolumn{5}{c}{ SA Concentration $\left.\mathbf{( m g} \cdot \mathbf{L}^{-\mathbf{1}}\right)$} \\
\cline { 2 - 6 } & $\mathbf{0}$ & $\mathbf{1}$ & $\mathbf{1 0}$ & $\mathbf{2 5}$ & $\mathbf{1 0 0}$ \\
\hline Bushehr & $0.076 \mathrm{~b}$ & $0.103 \mathrm{ab}$ & $0.086 \mathrm{~b}$ & $0.100 \mathrm{ab}$ & $0.103 \mathrm{ab}$ \\
Bona & $0.100 \mathrm{ab}$ & $0.093 \mathrm{ab}$ & $0.093 \mathrm{ab}$ & $0.126 \mathrm{a}$ & $0.090 \mathrm{~b}$ \\
Bodegold & $0.086 \mathrm{~b}$ & $0.076 \mathrm{~b}$ & $0.093 \mathrm{ab}$ & $0.096 \mathrm{ab}$ & $0.096 \mathrm{ab}$ \\
\hline
\end{tabular}

Table 12. Mean comparison for essential oil $\%(w / w)$ of chamomile treated with salicylic acid under heat stress conditions.

\begin{tabular}{cccccc}
\hline \multirow{2}{*}{ Cultivar } & \multicolumn{5}{c}{ SA Concentration $\left(\mathbf{m g} \cdot \mathbf{L}^{-\mathbf{1}}\right)$} \\
\cline { 2 - 6 } & $\mathbf{0}$ & $\mathbf{1}$ & $\mathbf{1 0}$ & $\mathbf{2 5}$ & $\mathbf{1 0 0}$ \\
\hline Bushehr & $0.090 \mathrm{a}$ & $0.090 \mathrm{a}$ & $0.080 \mathrm{a}$ & $0.100 \mathrm{a}$ & $0.086 \mathrm{a}$ \\
Bona & $0.086 \mathrm{a}$ & $0.090 \mathrm{a}$ & $0.080 \mathrm{a}$ & $0.096 \mathrm{a}$ & $0.100 \mathrm{a}$ \\
Bodegold & $0.076 \mathrm{a}$ & $0.083 \mathrm{a}$ & $0.080 \mathrm{a}$ & $0.093 \mathrm{a}$ & $0.100 \mathrm{a}$ \\
\hline
\end{tabular}

\section{Conclusions}

In summary, the results of this experiment illustrated that heat stress caused a significant reduction in the physiological characteristics (including plant height, capitol diameter, fresh flower weight and dried flower weight) and chlorophyll content, but it had no significant effect on the essential oil content. However, the proline content increased in response to heat stress. The lack of effect of the salicylic acid on the chlorophyll and essential oil content may be due to plant species, genotype and the high intensity of heat stress. Severe heat stress changes the secondary metabolites pathway and impairs 
plastid and chlorophyll structures. Also, severe heat stress reduced the improving effect of salicylic acid in the field conditions. In addition, it can be attributed to different responses of chamomile genotypes to specific concentrations and/or certain ranges of exogenous salicylic acid. Nevertheless, the response of chamomile cultivars was different to salicylic acid concentrations under normal and heat stress conditions. Regarding these results, chamomile can be proposed as a moderate heat-resistant medicinal plant with an admissible yield. Findings of this research may support the positive effect of plant growth regulators such as salicylic acid on the amelioration of quality and quantity of chamomile essential oil content under normal abiotic stress such as heat stress. Furthermore, it seems that more investigations are required in order to elucidate physiological and biochemical mechanisms of heat tolerance in German chamomile.

Acknowledgments: We gratefully acknowledge the faculties, staffs and technicians of the Bushehr Research Center for Agriculture and Natural Resources, Borazjan, Bushehr, Iran for the providing research field in the present investigation. Further, we declare our special thanks to the Persian Gulf Research and Study Institute, Persian Gulf University, Bushehr, Iran and Sari Agricultural Sciences and Natural Resources University, Sari, Mazandaran, Iran for their valuable support and cooperation. Our special thanks also goes to Farzad Najafi for providing seeds and his valuable scientific advice during this research. Gratitude also goes to Magaji Usman for constructive criticism and manuscript critical reading.

Author Contributions: M.M. and N.B.J. conceived and designed the experiments; M.G. performed the experiments; M.M., N.B., and M.G. analyzed the data; M.G. and A.J. contributed reagents/materials/analysis tools; M.G. and M.M. wrote the paper.

Conflicts of Interest: The authors declare no conflict of interest.

\section{References}

1. Kovacik, J.; Gruz, J.; Backor, M.; Strnad, M.; Repcak, M. Salicylic acid-induced changes to growth and phenolic metabolism in Matricaria chamomilla plants. Plant Cell Rep. 2009. [CrossRef]

2. Snyman, M.; Cronje, M.J.; Park, A.; Africa, S. Modulation of heat shock factors accompanies salicylic acid-mediated potentiation of Hsp70 in tomato seedlings. J. Exp. Bot. 2008, 59, 2125-2132. [CrossRef] [PubMed]

3. Larkindale, J.; Huang, B. Effects of abscisic acid, salicylic acid, ethylene and hydrogen peroxide in thermotolerance and recovery for creeping bentgrass. Plant Growth Regul. 2005, 47, 17-28. [CrossRef]

4. Yousefzadi, M.; Sharifi, M.; Moyano, E.; Palazon, J. Salicylic acid improves podophyllotoxin production in cell cultures of Linum album by increasing the expression of genes related with its biosynthesis. Biotechnol. Lett. 2010, 32, 1739-1743. [CrossRef] [PubMed]

5. Mustafa, N.; Kim, H.; Choi, Y.; Verpoorte, R. Metabolic changes of salicylic acid-elicited Catharanthus roseus cell suspension cultures monitored by NMR-based metabolomics. Biotechnol. Lett. 2009, 31, 1967-1974. [CrossRef] [PubMed]

6. Kova, J.; Bac, M. Salicylic acid alleviates NaCl-induced changes in the metabolism of Matricaria chamomilla plants. Ecotoxicology 2009, 18. [CrossRef]

7. SoloUKi, M.; Mehdikhani, H.; Zeinali, H.; Emamjomeh, A.A. Study of genetic diversity in Chamomile (Matricaria chamomilla) based on morphological traits and molecular markers. Sci. Hortic. J. 2008, 117, 281-287. [CrossRef]

8. Jeshni, M.G.; MoUSAvinik, M.; Khammari, I.; Rahimi, M. The changes of yield and essential oil components of German Chamomile (Matricaria recutita L.) under application of phosphorus and zinc fertilizers and drought stress conditions. J. Saudi Soc. Agric. Sci. 2015. [CrossRef]

9. Farhoudi, R.; Lee, D.-J.; Hussain, M. Mild Drought Improves Growth and Flower Oil Productivity of German Chamomile (Matricaria recutita L.). J. Essent. Oil Bear. Plants 2014, 17, 26-31. [CrossRef]

10. Baghalian, K.; Abdoshah, S.; Khalighi-sigaroodi, F.; Paknejad, F. Physiological and phytochemical response to drought stress of German chamomile (Matricaria recutita L.). Plant Physiol. Biochem. 2011, 49, 201-207. [CrossRef] [PubMed]

11. Salimi, F.; Shekari, F.; Hamzei, J. Methyl jasmonate improves salinity resistance in German chamomile (Matricaria chamomilla L.) by increasing activity of antioxidant enzymes. Acta Physiol. Plant 2016, 38, 1. [CrossRef] 
12. Rowshan, V.; Bahmanzadegan, A. Effects of salicylic acid on essential oil components in Yarrow (Achillea millefolium Boiss ). Int. J. Basic Sci. Appl. Res. 2013, 2, 347-351.

13. Rafieiolhossaini, M.; Sodaeizadeh, H.; Adams, A.; De Kimpe, N.; Van Damme, P. Effects of planting date and seedling age on agro-morphological characteristics, essential oil content and composition of German chamomile (Matricaria chamomilla L.) grown in Belgium. Ind. Crops Prod. 2010, 31, 145-152.

14. Salamon, I. Effect of the internal and external factors on yield and qualitative characteristics of chamomile essential oil. In Proceeding of the I International Symposium on Chamomile Research, Development and Production, Presov, Slovak Republic, 7-10 June 2006; ISHS Acta Horticulturae: Leuven, Belgium.

15. Razmjoo, K.; Heydarizadeh, P.; Sabzalian, M.R. Effect of Salinity and Drought Stresses on Growth Parameters and Essential Oil Content of. Int. J. Agric. Biol. 2008, 10, 451-454.

16. Salamon, I. Chamomile Biodiversity of the Essential oil Qualitative-Quantitative Characteristics; Springer Press: Dordrecht, The Netherlands, 2009; pp. 83-90.

17. D'Andrea, L. Variation of Morphology, Yield and Essential Oil Components in Common Chamomile (Chamomilla recutita (L.) Rauschert) Cultivars Grown in Southern Italy. J. Herbs Spices. Med. Plants 2002, 37-41. [CrossRef]

18. Rampino, P.; Lupotto, E.; Marmiroli, N.; Perrotta, C. The effect of heat stress and cadmium ions on the expression of a small Hsp gene in barley and maize. J. Cereal Sci. 2005, 42, 25-31.

19. Wahid, A.; Gelani, S.; Ashraf, M.; Foolad, M.R. Heat tolerance in plants: An overview. Environ. Exp. Bot. 2007, 61, 199-223. [CrossRef]

20. Usman, M.G.; Rafii, M.Y.; Ismail, M.R.; Malek, M.A.; Latif, M.A. Expression of Target Gene Hsp70 and Membrane Stability Determine Heat Tolerance in Chili Pepper. J. Am. Soc. Hortic Sci. 2015, 140, 144-150.

21. Al-whaibi, M.H. Plant heat-shock proteins: A mini review. J. King Saud Univ. Sci. 2011, 23, 139-150. [CrossRef]

22. Heidari, M.; Sarani, S. Growth, biochemical components and ion content of Chamomile (Matricaria chamomilla L.) under salinity stress and iron deficiency. J. Saudi Soc. Agric. Sci. 2012, 11, 37-42. [CrossRef]

23. Usman, M.G.; Rafii, M.Y.; Ismail, M.R.; Malek, M.A.; Latif, M.A. Heritability and Genetic Advance among Chili Pepper Genotypes for Heat Tolerance and Morphophysiological Characteristics. Sci. World J. 2014, 1-14. [CrossRef] [PubMed]

24. Hayat, S.; Masood, A.; Mohammad, Y.; Ahmad, A.; Fariduddin, Q. Growth of Indian mustard (Brassica juncea L.) in response to salicylic acid under high-temperature stress. Brazil. J. Plant Physiol. 2009, 21, 187-195. [CrossRef]

25. Mohammadi, V.; Bihamta, M.-R.; Zali, A.-A. Evaluation of screening techniques for heat tolerance in wheat. Pakistan J. Biol. Sci. 2007, 10, 887-892. [CrossRef]

26. Modarresi, M.; Mohammadi, V.; Zali, A.; Mardi, M. Response of Wheat Yield and Yield Related Traits to High Temperature. Cereal Res. Commun. 2010, 38, 23-31. [CrossRef]

27. Modhej, A.; Naderi, A.; Emam, Y.; Aynehband, A. Effects of post-anthesis heat stress and nitrogen levels on grain yield in wheat (T. durum and T. aestivum) genotypes. Int. J. Plant Prod. 2008, 2, 257-268.

28. Ayeneh, A.; Van Ginkel, M.; Reynolds, M.P.; Ammar, K. Comparison of leaf, spike, peduncle and canopy temperature depression in wheat under heat stress. Field Crop. Res. 2002, 79, 173-184. [CrossRef]

29. Midmore, D.J.; Cartwright, P.M.; Fischer, R.A. Wheat in tropical environments. II. Crop growth and grain yield. Field Crop. Res. 1984, 8, 207-227. [CrossRef]

30. Lichtenthaler, H.K. Chlorophylls and carotenoids: Pigments of photosynthetic biomembranes. Methods Enzymol. 1987, 148, 350-382.

31. Bates, L.S.; Waldern, R.P.; Teave, I.D. Rapid determination of free proline for water stress studies. Plant Soil 1973, 39, 205-207. [CrossRef]

32. Kumar, R.R.; Goswami, S.; Sharma, S.K.; Singh, K.; Gadpayle, K.A.; Kumar, N.; Rai, G.K.; Singh, M.; Rai, R.D. Protection against heat stress in wheat involves change in cell membrane stability, antioxidant enzymes, osmolyte, $\mathrm{H}_{2} \mathrm{O}_{2}$ and transcript of heat shock protein. Int. J. Plant Physiol. Biochem. 2012, 4, 83-91.

33. Khalid, K.A.; Teixeira, J.A. Yield, essential oil and pigment content of Calendula officinalis L. flower heads cultivated under salt stress conditions. Sci. Hortic. (Amsterdam) 2010, 126, 297-305. [CrossRef]

34. SAS Institute. SAS Users Guide: Statistics Version 6th Edn; SAS Institute Inc.: Cary, NC, USA, 1996. 
35. Alexandra, S. German Chamomile (Matricaria Chamomilla L.) Population Morphological and Chemical Diversity; Budapest University: Budapest, Hungary, 2005.

36. Hussain, M.; Malik, M.A.; Farooq, M.; Khan, M.B.; Akram, M.; Saleem, M.F. Exogenous glycinebetaine and salicylic acid application improves water relations, allometry and quality of hybrid sunflower under water deficit conditions. J. Agron. Crop Sci. 2009, 195, 98-109. [CrossRef]

37. Farooq, M.; Wahid, A.; Kobayashi, N.; Fujita, D.; Basra, S.M.A. Plant drought stress: Effects, mechanisms and management. Agron. Sustain. Dev. 2009, 29, 185-212.

38. Circella, G.; De Mastro, G.; Nano, G.M.; D’Andrea, L. Comparison of Chamomile Biotypes (chamomilla recutal Rauschert). In Proceeding of the WOCMAP I-Medicinal and Aromatic Plants Conference, Maastricht, The Netherlands, 1 April 1993; ISHS Acta Horticulturae: Leuven, Belgium.

39. Golparvar, A.R.; Pirbalouti, A.G.; Karimi, M. Determination of the effective traits on essence percent and dry flower yield in German chamomile (Matricaria chamomilla L.) populations. J. Med. Plants Res. 2011, 5, 3242-3246.

40. Taviana, P. Variation for agronomic and essential oil traits among wild populations of Chamomilla recutita (L.) Rausch. from Central Italy. J. Herbs Spices Med. Plant 2001, 9, 1049-6475.

41. Amani, A.L. Cadmium induced changes in pigment content, ion uptake, proline content and phosphoenolpyruvate carboxylase activity in Triticum aestivum seedlings. Aust. J. Basic Appl. Sci. 2008, 2, $57-62$.

42. Abd El-Baky, H.H.; Hussein, M.M.; El-Baroty, G.S. Algal extracts improve antioxidant defense abilities and salt tolerance of wheat plant irrigated with sea water. Electron. J. Environ. Agric. Food Chem. 2008, 7, 2812-2832.

43. El-Khallal, S.M.; Hathout, T.A.; Ashour, A.E.A.; Kerrit, A.A.A. Brassinolide and salicylic acid induced growth, biochemical activities and productivity of maize plants grown under salt stress. Res. J. Agric. Biol. Sci. 2009, $5,380-390$.

44. Wang, L.-J.; Fan, L.; Loescher, W.; Duan, W.; Liu, G.-J.; Cheng, J.-S.; Luo, H.-B.; Li, S.-H. Salicylic acid alleviates decreases in photosynthesis under heat stress and accelerates recovery in grapevine leaves. BMC Plant Biol. 2010, 10, 34. [CrossRef] [PubMed]

45. Efeoglu, B.; Terzioglu, S. Photosynthetic responses of two wheat varieties to high temperature. EurAsia. J. BioSci. 2009, 3, 97-106. [CrossRef]

46. Reda, F.; Mandoura, H.M.H. Response of enzymes activities, photosynthetic pigments, proline to low or high temperature stressed wheat plant (Triticum aestivum L.) in the presence or absence of exogenous proline or cysteine. Int. J. Acad. Res. 2011, 3, 108-115.

47. Ashraf, M.; Harris, P.J.C. Photosynthesis under stressful environments: An overview. Photosynthetica 2013, 51, 163-190. [CrossRef]

48. Johari-Pireivatlou, M. Effect of soil water stress on yield and proline content of four wheat lines. Afr. J. Biotechnol. 2010, 9, 36-40.

49. Baghalian, K.; Haghiry, A.; Naghavi, M.R.; Mohammadi, A. Effect of saline irrigation water on agronomical and phytochemical characters of chamomile (Matricaria recutita L.). Sci. Hortic. 2008, 116, 437-441. [CrossRef]

50. Bita, C.E.; Gerats, T. Plant tolerance to high temperature in a changing environment: Scientific fundamentals and production of heat stress-tolerant crops. Front. Plant Sci. 2013, 4, 1-18. [CrossRef] [PubMed]

51. Presibella, M.M.; Villas-Boas, L.D.B.; Belletti, K.M.D.S.; Santos, C.A.D.M.; Weffort-Santos, A.M. Comparison of chemical constituents of Chamomilla recutita (L.) Rauschert essential oil and its anti-chemotactic activity. Braz. Arch. Biol. Technol. 2006, 49, 717-724. [CrossRef]

52. Flexas, J.; Medrano, H. Drought-inhibition of photosynthesis in C3 plants: Stomatal and non-stomatal limitations revisited. Ann. Bot. 2002, 89, 183-189. [CrossRef] [PubMed]

53. Priyadarshi, S.; Borse, B.B. Effect of the Environment on Content and Composition of Essential oil in Coriander. Int. J. Sci. Eng. Res. 2014, 5, 57-65.

54. Kwiatkowski, C.A. Yield and quality of chamomile (Chamomilla recutita (L.) Rausch.) raw material depending on selected foliar sprays and plant spacing. Acta Sci. Pol. Hortorum Cultus 2015, 14, 143-156.

(C) 2016 by the authors; licensee MDPI, Basel, Switzerland. This article is an open access article distributed under the terms and conditions of the Creative Commons Attribution (CC-BY) license (http://creativecommons.org/licenses/by/4.0/). 